\title{
Space Prospect in the Flexible Era of Late Capitalism
}

\author{
Nihan Muş Özmen ${ }^{1 \odot}$, Burak Asiliskender² ${ }^{\circledR}$ \\ ${ }^{1}$ Lecturer, Faculty of Architecture, Abdullah Gül University, Kayseri, Turkey. (Principal contact for editorial correspondence), \\ Email: nihan.mus@agu.edu.tr \\ ${ }^{2}$ Prof. Dr., Faculty of Architecture, Abdullah Gül University, Kayseri, Turkey. Email: burak.asiliskender@agu.edu.tr
}

\begin{abstract}
This study is mainly influenced by the idea of Manfredo Tafuri that architecture cannot fulfil its ideological task since it started serving capitalism and there are no more utopias. In his book Architecture and Utopia: Design and Capitalist Development, Tafuri discusses the sociophilosophical tangle in which architects have been struggling since the 18th century. According to Tafuri, the drama of today's architecture is the obligation to return to pure architecture, a matter of form without utopia, supreme uselessness.

Another influence on the study is Richard Sennett's book The Corrosion of Character. Sennett mentions the concept of flexible capitalism and explains that work life is not as rigid as it was before. According to Sennett, flexibility has an impact on personal character and asks questions about how to decide the lasting value of we in an impatient society, how to pursue a long-term goal in a short-term economy, how to sustain loyalties to the continually redesigning institutions.

Purpose

The thoughts of Tafuri and Sennett are discussed through Patrik Schumacher's Parametricism manifesto. In the manifesto, Schumacher reflects architecture's evolving patterns of communication in relation to its social task. The main objective of the study is to propose a future space based on the ideas of Tafuri, Sennett and Schumacher.

Design/Methodology/Approach

This paper discusses the reviews of books of Tafuri and Sennett and manifesto of Schumacher as a methodology.

\section{Findings}

After the reviews of The Corrosion of Character and Architecture and Utopia, there is a discussion of flexible space through parametric design approach. Finally, there is the prediction of future space based on the findings in the previous sections.

\section{Research Limitations/Implications}

There are no research limitations for this paper.

Social/Practical Implications

According to this paper, parametric design method can be used in practice to achieve the spaces that are needed by the complex society of global era.

Originality/Value

This paper synthesizes the ideas of two great thinkers, who have influential discourses on architecture and business world, and approaches them from the perspective of parametric design as one of today's design tools, to make predictions about the future space.
\end{abstract}

Keywords: Flexible labour, flexible space, workspace, parametric design 


\section{INTRODUCTION}

New in, old out. The consumerism which was created by late Capitalism has been more than just purchasing. The consumption of the produced goods, the creation of new requirements through new goods has forced consumers for rapid adaptation to these new requirements. For example; we really did not feel the need for cell phones before they were produced, but now we cannot live without them. We consume everything quickly - relationships, places, etc. - as a result of this rapid adaptation. Even though it is worthwhile to protect the values we inherit, it is now more valuable to ensure the fastest adaptation to new changes. The communication era, which is created by late capitalism and globalization, has also affected business life. In this global era, work life is forced to be global and outsourced because of the production processes (raw materials, supplier industry, market, know-how, etc.). This leads white collars, who carry out bureaucratic works of the companies, to be global and mobile. As the servants of consumerism, the white-collars - the workers of the information era - should be flexible and have multiple abilities in order to keep up with the change of situations and to be successful in different business fields.

In today's world, there is a common opinion that immaterial (1) labour must be flexible. When the career paths of today's white-collar workers are examined in detail, the evidence of this flexibility could be found. Richard Sennett (1998) mentions in his book The Corrosion of Character that in forty years of labour, an educated worker should change his/her job at least eleven times and skills at least three times.

While capitalism is determinative in our lives, how has it affected architecture? Tafuri (1976) answers this question in his book Architecture and Utopia that architecture is not a directive tool anymore because it serves capitalism. Architects are not ideologues of society as they were in the past.

Nowadays, Sennett says that labour is changing, and it should be flexible. He speaks about the change in the labourer and how labour should be shaped. In addition, Tafuri speaks of the change in architecture along with capitalism and questions the ideological task of architecture. Schumacher states that societies are complex and diverse and the structures that will respond to the societies can be implemented with parametric design, which is one of the contemporary design approaches. In light of these important ideas, the task of the architect and the space of the future is questioned in this study.

The question raised by this diversification was; should architecture maintain its rigidity in the global era while everything is flexible? Parametric design, as one of the contemporary design approaches, may answer this question. Based on the concerns mentioned above, this study questions how architecture should respond to the needs of life in the flexible era of today by interpreting the task of architecture towards society, based on the perspective of Tafuri. In addition, this study proposes a future space based on scenarios of how future lifestyle is 
going to be. Is this change going to be present in the future? Or is it going to stop?

\section{FLEXIBLE LABOUR IN LATE CAPITALISM}

Richard Sennett (1998) explores the effects of what he calls the new economy or new capitalism on the lives of workers in his studies. He reveals how the work undermines and degrades the identities of workers in the late capitalism's flexible production process and leads to corrosion of character. Sennett notifies that because of long-term attachments to large companies, the corrosion of character and ultimate breakdown of society is inevitable. In the global age, because the capital is more flexible than ever before, the flexibility of the production process and also the flexibility of labour have changed the nature of labour. According to Sennett, some negative effects on the personality of the individual and corrosion of character are caused by the flexible working conditions that affect not only the working life of employees but also daily life activities.

On the other hand, the state's position as the biggest employer in the new capitalism has come to an end. Today multinational companies are geographically and spatially flexible in the organisation of new capitalism, local companies organized around these companies and subcontractors offer employment opportunities. As Sennett mentions, the idea of being able to work for a lifetime in a single institution under new working conditions is now a dream.

Sennett stated that a new pyramid emerged, unlike traditional production and management. "Specifically, this new structure performs like an MP3 player. The MP3 machine can be programmed to play only a few bands from its repertoire; similarly, the flexible organization can select and perform only a few of its many possible functions at any given time" (Sennett, 2007, pp. 47-48)

In the book The Corrosion of Character: The Personal Consequences of Work in the New Capitalism, Richard Sennett (1998) discusses the impact of the capitalist economy on the lives of labourers. "He views each life as an ongoing story, structured by the passage of time and highlighted by significant career-related events" (Magill, 2005). Sennett follows the current economy's development briefly and evaluates its effects on the lives of people, rather than criticizing the economy itself. He also asks some questions about how to create long-term purposes in a short-term society, how to sustain durable social relations, how to develop a story of character and life history in a society made out of episodes and fragments.

Sennett (1998) defines work, which provided workers identity and security before the mid-twentieth century, as a fixed scale used to measure success. He contrasts this experience with American workers' current situation and uses personal examples to illustrate his points. "One administrative assistant told me, 'Each time you start a new job, you need to fake it. The boss expects you know how things should be 
done and what he wants. But of course, you don't. It's a challenge'" (Sennett, 2007, p. 50). "The mental world here is operational, process divorced from content" (Sennett, 2007, p. 118). “... this purely operational thinking requires mental superficiality" (Sennett, 2007, p. 120).

"Work is not a pos-session, nor does it have fixed content, but becomes instead a position in a constantly changing network" (Sennett, 2007, p. 140). Sennett (1998) describes the modern economy as flexible capitalism, which is the goal of most modern businesses to make continuous changes in order to fit into the market. Sennett looks at working conditions in the new flexible economy and sees many problems. "There's no predictability, no long-term commitment, no long-term relations with co-workers and bosses, no loyalty, more confusion, etc. Most of all, the new work environment makes it more difficult to find and maintain a narrative of your work life" (Kjerulf, 2004). Sennett also tells the stories of other American middle-aged workers facing contradictions in the workplace and demonstrating how they cope with the risks they face. Through these personal stories, he illuminates the ethical disadvantages of the capitalist system that has brought the American economy to power.

According to Sennett (1998), the cornerstone of modern management is the belief that loose networks are more open to decisive reinvention than pyramid hierarchies like the Fordist era. The junction in the network between the nodes is more relaxed, a part can be removed without damaging other parts. Flexible specialization is the complete antithesis of the production system embodied in Fordism (Sennett, 1998). He also points out that work ethic of this era is different; it is more collaborative and more forgiving. Because of collaborative work life, there are groups in the workspaces that share superficiality. People in those groups stay together by avoiding personal and difficult questions, hence teamwork can be seen as the bonds of group conformity.

In reality, it is hard to achieve qualified white-collar jobs; it requires a good education that lasts for years. The education you receive is not unifying, it is discriminatory; your frequency of interaction with people who are not like you is reduced, on the other hand, you are directed to a specific place in terms of employment opportunities. In addition, you are forced into a very hard race with many people, including your friends to find the job of your life and thus begin the corrosion process of your character that will last throughout your working life (Özmen, 2017).

\section{ROLE OF ARCHITECTURAL DESIGN}

In his book Architecture and Utopia: Design and Capitalist Development, Tafuri (1976) mentions that architecture is in a downfall proportional to the development of capitalism. Although this conversion is very certain in architecture, architects are in uncertainty according to him. He states 
that architecture is divested from its most important mission, ideology, by the capitalist development. The shock which is created by the large city experience rises from the contradictions of capitalism and it created alienation. According to Tafuri, bourgeoisie art and ideology struggled to close the distances between ethical morals and obligations in the world of capitalism. At the beginning of the capitalist development, the task of architect was to act as the ideologist of the society, to intervene individually with city planning, to be successful and to insist on the forms he/she produces for people. In addition, his/her forms had to contain the questions to criticise itself about social development and its own development (Tafuri, 1976).

Tafuri continues that city ideologies entered a new period at the end of the 19th century with the approach of Marxist criticism and directed towards a social problem. Its origin and incidence of realism revealed the delusion of utopianism. In the $20^{\text {th }}$ century, social utopianism collapsed, and architecture became a form utopia. He states that eventually, the first industry that understood the effects of commodification was modern architecture, so architects tried to integrate the new capitalist city's order of production, consumption, and distribution.

According to Tafuri (1976, p. 50) ideology became both repellent and attractive by serving capitalism. It was expected to create global models without social purposes and to gain a social form of consumption. Therefore, ideology turned into the capitalist-industrial utopia. He claims that ideology existed between a specific place and class service so that creating a form no longer meant regulating society and the motto form follows function is a reflection of this reality. It is important to discourage people to look for heaven, "salvation lies no longer in 'revolt', but in surrender without discretion" (Tafuri, 1976, p. 74).

In the period - defined by Tafuri as the downfall of reason-industrial production was the cause of the annihilation of labour, which caused the shock. People were degraded to machine parts and alienation was growing. In the new urban ideology, everything was in commercialization and commodification. Because of this, consumption ideology (2) was shown as the best usage of the city. According to him, what is avant-garde now is industrial design.

Tafuri mentions that architecture ideology has no more a directive role in the capitalist development. In the last part of his book Tafuri tries to find an answer to the question; "What can be done?" The fact that building production continues to override the architectural ideology and economic social forces ignore the rationalization of the architectural ideology of urban order and points to renewal in planning. Therefore, the functional position and the ideology of the planner and planning must be redefined in accordance with this. He mentions that the urban and regional efforts in accordance with the benefits of employees are needed to be at a level that they consider the complex programs, criticize them and develop consistent alternatives to them. Now, what is 
expected to be designed is a flexible social values system. In this sense planning turns into a tool of hegemony (Ertekin, 1981). Tafuri claims that the ideology of design is one of the most important requirements of modern capitalism; it is a consolidation tool as Corbusier determined. What is needed is to criticize and to add a political dimension to the architectural ideology. Only then the roles (designer, planner, etc.) in the field is going to be possible to handle in the capitalist development.

As can be seen, Tafuri situates some key points about the process of architecture after capitalism. "Architecture is for Tafuri supreme among the arts simply because its Other or exterior is coeval with History and society itself, and it is susceptible therefore to the most fundamental materialist or dialectical reversal of all" (Jameson, 1982, p. 449). Therefore, he considers the role of architect as the ideologist -directing the society through the spaces he/she creates- of the society. Tafuri mentions that the capitalist development caused the loss of the mission of architectural ideology. "Having arrived at an undeniable impasse due to the inherent contradictions of capitalist development, architectural ideology gives up its role as stimulus to the structures of production and hides behind ambiguous slogans contesting the 'technological civilization"' (Tafuri, 1969, p. 29). In addition, it faces being useless. "'Artistic' uselessness, which one can also trace in the new architecture, is subtended, in the avant-garde, by a refusal; architecture, on the other hand, attains it through the necessity that binds the image to reality' (Scolari, 1973, p. 130). Thus, the eclecticism movement arises in order to find a way out of this uselessness.

"Trying to find a space out of the system of production in which to relocate the work of the architect as intellectual, Tafuri realizes that the only possible place to re-locate architecture was outside the ideology" (Diaz, 2012). He thinks that the architect should have a new mission and consider the city as a social machine. Architecture became dependent upon capitalism and the public was made to believe that consumption is the best usage of the city. Moreover, instead of just being a designer, the architect should be an organizer and invite the public to participate in the consumption of the city.

Finally, Tafuri remarks that industrial design has the clue of being utopic and it is the new avant-garde. It creates the city through advertisements. As Akın (2005) stated, Smithsons said that advertisements try to sell a natural accessory of a way of life packed by informatics, not a product and the advertisements of mass production objects aim to establish a whole life pattern: principles, ethics, goals, associations, the standard of living. Hence, what is expected from architecture is creating a flexible social values system.

There are two main arguments - urban paths- of Tafuri that ideology turned into capitalist industrial utopia and industrial design is a new utopic sign. Ideology is a way of thought and the utopia is a designed form of ideology, so that both of them refer to an ideal thing. According to Tafuri, in order to suffer from this crime, ideology had to turn into 
utopia because it was accused of being productive. As a result of the uncertainty that architecture falls in because of capitalism, it began to serve as an integral part of mass production. So, how does architecture serve capitalism? As in every sector, the industrialization that occurred in building production created standardization. According to Tafuri, instead of suggesting methods or models, architecture consists of gathering manufactured parts of mass production. From the ideological point of view of Tafuri, architecture no longer directs society with its forms; it becomes a means of capitalist production. The society is convinced that consumption is the most ideal way of life and it symbolizes the downfall of reason by serving it.

The question here is; is it a negative situation as Tafuri sees, that architecture serving to capitalism? What did architecture serve before capitalism? Architecture that serves to capitalism as the power element of contemporary world, served to power also in the past, for example, churches in the Middle Ages and Ancient Greek aristocracy. We can see that the working class in capitalism is similar to the peasant in the Middle Ages and the slaves in Ancient Greek. Moreover, certain freedoms of the working class are protected by law in the world where slaves had no freedom. When we have a look at architecture, for example, churches were located in the centre of all the cities established in the Middle Ages, and the architectural styles contained spiritual images. Even today, it is possible to read these traces as we look at the towns established in the Middle Ages. Architecture has adapted itself to this phase, like other disciplines, in the inevitable era in which mass production arose as a result of technological developments and the industrial revolution became a dominant power. Architecture, which adapts to the new process, can still fulfil its ideological missions, which are also realized by the structures for the new lifestyles that it creates. Tafuri was thinking that modern architecture was in a crisis; however, this crisis was not a result of exhaustion. The real reason was that there was a crisis in architectural ideologies. In other words, architecture was attached strongly to the ideology and so, it was politicized (Aras, 2015, p. 102). After capitalism, the rapidly developing industrial design products and the advertising used to promote them became the constituents of the city. Now, the expectation from architecture setting up a system of flexible social values based on the social machine logic.

\section{PARAMETRIC DESIGN AND FLEXIBLE SPACE}

In The Autopoiesis of Architecture I: A New Framework for Architecture (2011) and The Autopoiesis of Architecture II: A New Agenda for Architecture, Patrik Schumacher (2012) defines the contemporary architectural style as Parametricism (3). Parametricism approach is based on the idea that architecture is a communication tool. "The unique, societal function of architecture: to order and frame communicative interaction" (Schumacher, 2016b). The perception of the 
identity of space gives us clues about it, with the cognition; we decide how to behave in that space. Schumacher (2016a, p. 109) states that:

The social functionality of architecture resides to a large extent in its communicative capacity. The built environment orders social processes through its pattern of spatial separations and connections that in turn facilitates a desired pattern of separate and connected social events. This is social organisation via spatial organisation.

The interaction is not just between people, but between people and the built environment as well, the built environment also creates interaction between people. "The whole built environment must become an interface of multi-modal communication, as the ability to navigate dense and complex urban environments has become a crucial aspect of today's overall productivity" (Schumacher, 2013b). As Kamp states, "the interaction takes place in an environment" (Kamp, Veen, \& Vink, 2015, p. 281). Moreover, communicating is not only about consuming space and spending time in it, but any relationship with space is communication. "Both a designed space and the act of entering the space are communications" (Schumacher, 2015).

Even though "every design is driven by the constraints of the site, brief, environmental conditions and local planning requirements, rather than based on standard 'typologies' or customisable templates" (Bell \& Simpkin, 2013, p. 89), architecture is innovative, theory-led and architectural knowledge and spatial organisation has gained a new approach by parametric design. It is available to create spaces that have strong characteristics. "Parametric design is a powerful methodology to achieve a new architectural morphology, namely a morphology of continuous differentiation" (Schumacher, 2016b). It is a rule-based differentiation and correlation system, morphology of continuous differentiation. It is an ordered complexity. It is possible by parametric design to increase the information about the built environment.

Parametric design, conceived as a network of relationships or dependencies, establishes relationships between various elements of the composition. Parametric design builds up a connection between architectural geometry and performative parameters of climate, structure, material, and behaviour. "The designer might choose and calibrate the adaptive correlations between the subsystems so that the different systems do indeed become 'representations' of each other in the sense that users navigating the urban environment can not only follow the gradients or vectors of transformation in each of the subsystems" (Schumacher, 2016d). This design method has an important advantage that as new information is fed into the design process, the detail solution and the build-up of the design complexity can progress simultaneously with maintaining the malleability to adapt to the changing requirements. Also, "parametricism that allow contemporary architects to ramp up the communicative complexity of the built environment are also congenial to the agenda of optimizing 
architectural forms with respect to ecological performance criteria" (Schumacher, 2010a). Considering that architecture is responsible for the social functionality of the built environment, "this powerful enhancement of the communicative capacity of the built environment via rule-based parametric design goes to the heart of architecture's societal function of ordering the multitude of social interaction scenarios that make up contemporary society" (Schumacher, 2016b). Architects need to analyse the sociological drive of the life processes of clients and strategically introduce their ordering capacity into the game. "The task is to design an information rich, dense built environment that orders and codes/reveals the manifold social interactions to be expected within its spaces" (Schumacher, 2013a). The designer devises and formulates rules or correlations much the same as the laws of nature.

Architecture is one of those great function systems of contemporary society that is functionally differentiated, and architecture is actively involved in the evolution of society. "The mass society that was characterised by a universal consumption standard has evolved into the heterogeneous society of the multitude, marked by a proliferation of lifestyles and extensive work-path differentiation" (Schumacher, 2008). From the perspective that architecture should be a tool for organizing social processes, "society demands that architecture has to adapt" (Schumacher, n.d.-b). If all the problems of society are communication issues, communication emphasis is a prerequisite for rising social effectiveness of architecture. "Form powers function. That's the new thesis. Spatial organization sustains social organization" (Schumacher, 2010b).

Schumacher refers that mass society is very diverse in the global era, which is a similar thought of Sennett. Each of us has the skills we need for the business world and the qualities we have to be able to exist in social life in different environments. Therefore, we live with all these diversities and consume spaces accordingly.

Another point that Schumacher emphasizes is similar to Tafuri's architectural ideology thought. By mentioning that architecture should direct social processes, he changes the famous statement of Mies van der Rohe form follows function into form powers function. According to this, architecture, which can direct social relations with its form, can respond to the diversity of society.

Parametricism is versatile and rich, it has the associative tools to build up the complex, a variety of order that contemporary society requires. "Parametricism is not only a new methodology for generating form but also a new paradigm of understanding social function" (Schumacher, 2014). Llabres \& Rico (2012, p. 85) states that "design is making sense (of things). It is, therefore, the task of the designer to understand both the target audience and the project in order to strike a balance between parameters, values and tacit forms of algorithms". Parametric design offers a new, dynamic order through concepts of distinction and 
comparison, with the goal of intensifying internal dependencies in architectural design as well as external dependencies and consistency in a complex urban context. "Aesthetically, it is the elegance of ordered complexity and the sense of seamless fluidity, akin to natural systems that constitute the hallmark of parametricism" (Schumacher, 2009). Parametric design changes the homogeneous identification of modernism and differentiates it with its capacity to adapt to local site conditions, climates, contexts, etc. "Parametricism is architecture's answer to contemporary, computationally empowered civilization" (Schumacher, 2016c).

Our lives are constantly changing in the information era. We are moving constantly in this world where everything is evolving and consumed rapidly. We are traveling, trying to catch up and in a rush. While the time we spend anywhere becomes more limited, we gradually lose our sense of belonging to all places. In order to exist in this capitalist world, we need to be flexible individuals.

While the world and us, people are so flexible and mobile, architecture remains rigid. While it profits from the processes of capitalist production, it does not provide the flexibility that the capitalist life requires. As Tafuri mentioned, architecture, which was previously ideological, no longer fulfils this task and the question is here if architecture gets out of date.

Is it possible that architecture would find the answer in parametric design in order to respond to this variability? Is it possible that parametric design, which uses too many inputs, produces the spaces that people require? Is it possible that architects, who should be ideologues of the society, could lead the society through the forms they create with parametric design?

\section{CONCLUSIONS AND RECOMMENDATIONS}

To sum up the ideas of Sennett and Tafuri, flexibility and change are at the forefront in the world of late capitalism. Work life forces employees to be flexible. Architecture, on the other hand, serves capitalism using the means of production, but cannot fulfil its ideological task. Based on the claims of Patrik Schumacher in Parametricism manifesto, parametric design may be the method to design the spaces needed by this flexible and changing world, by using variable inputs to create differentiated spaces according to these inputs.

As Tafuri pointed out, architecture was leading society by performing an ideological task before capitalism. According to him, architecture lost its ideological task, because it is in a downfall by serving capitalism. Large cities that arose by mass production became the centre of alienation. Architecture could no longer resist this situation, salvation surrendered instead of revolt. The critical approach of Tafuri to the task of architecture in a capitalist world has led this paper to question the relationship between architecture and capitalism. 
Our lives go on roads, in airports, in shopping malls or in hotels. This is what the global era brings us. By means of neoliberal policies, capital began to circulate around the world, time and space are stuck. Economies are now revolving around structures where knowledge is organized at the centre, production and distribution are organized in the environment. Therefore, employees are forced to travel.

We go to and work in unidentified places during these travels. While production is so mobile, employees have to be mobile. Not only they have to be mobile, but also, they have to be flexible to keep up with the changing world and economy. Flexible labour is an important issue in the world that is created by late capitalism, which leads to corrosion of character. Employees, who have to develop different skills in order to be present in business life, create variations in the society with their diversity and with the current lifestyles in the global world that we are in. Everything is in rapid change. Architecture must adapt to this rapid change and diversity. Or, on the contrary, by adapting to the flexible world created by capitalism that architecture serves to, they can pave the way for social collapse and accelerate the process further.

Considering the discourse of Tafuri that architecture serves to capitalism, architects can create new spaces by making use of capitalist production tools. These new spaces can meet the needs of diverse societies where Sennett speaks of people who develop different skills to adapt to the flexible business life. In order to respond to the diversity, these spaces can be flexible like the individuals they serve to. These flexible spaces can adapt themselves to changing situations. Hereby, people can also create special and unique areas while being part of a space temporarily. Flexible, variable and unique spaces needed by the flexible society can be realized with parametric design which is mentioned by Schumacher in the Parametricism manifesto. With the help of parametric design, special spaces can be created which are specific to the place, can be shaped according to different parameters and even transformed individually. People may acquire the speciality they need in a space by transformations. While providing these designs by using parametric design to respond to variables, convertible spaces can also be provided by kinetic architecture.

Through these contributions, perhaps architects may really serve as social ideologues. Not only they do design spaces, but also, they may think about how these spaces are going to affect the lives of people. They may design spaces that serve to different functions and create spaces that are able to be transformed with the advantages of kinetic architecture which can respond to variabilities with the advantages of parametric design. In this way, architecture may not only serve to the flexible world of capitalism but also produce spaces that is live all the time. Thus, the vitality of the streets that Jane Jacobs mentions may be present in these living places. 


\section{ACKNOWLEDGEMENTS/NOTES}

(1) According to Hardt \& Negri (2000, p. 290) "Since the production of services results in no material and durable good, we define the labor involved in this production as immaterial labor-that is, labor that produces an immaterial good, such as a service, a cultural product, knowledge, or communication". For more information, see Empire (2000) by Hardt \& Negri.

(2) Industrial design was a new utopic sign although it was serving the necessities of the reorganisation of production. It was the discrepancy of Bauhaus.

(3) It would be good to make a personal note here. Even though I mostly agree with Schumacher's ideas about the complexity of society and parametric design can respond to the needs of this complex society, I disagree that parametric design is a style. I have similar thoughts with Gage (2016, p. 130) 'Schumacherian Parametricism' is neither a style nor a movement, but merely a now ubiquitous 21st-century technology coupled with a stylistic preference for topologically derived (smooth) digital surfaces - an aesthetic to which, in the interest of full disclosure, I also have affinities. Parametricism as a technology, however, inherently has no style, and can be used to support any number of 'styles'. There is no reason that a Tuscan-style suburban house cannot be technologically parametric - in fact, because of various building information modelling (BIM) technologies, most already are. As he mentions, instead of being a style, it is a design system that is based on correlations and it can benefit from the technological improvements. In addition, any style can be brought into life with this robust system even though the circumstances change".

\section{CONFLICT OF INTEREST}

No conflict of interest was declared by the authors.

\section{FINANCIAL DISCLOSURE}

The authors declared that this study has received no financial support.

\section{ETHICS COMMITTEE APPROVAL}

Ethics committee approval was not required for this article.

\section{LEGAL PUBLIC/PRIVATE PERMISSIONS}

In this research, the necessary permissions were obtained from the relevant participants (individuals, institutions and organizations) during the survey, in-depth interview, focus group interview, observation or experiment.

\section{REFERENCESS}

Akın, G. (2005). Brütalizm I. Betonart, 8, 48-71.

Aras, L. (2015). Tafuri ve Venturi'den öğrendiklerimiz. International Refereed Journal of Design and Architecture, 2(4), 98-110. 
Bell, B., \& Simpkin, S. (2013). Domesticating parametric design. Architectural Design, 83(2), 88-91.

Diaz, F. J. (2012, May). Is Tafuri Still Valid? A contemporary reading of Architecture and Utopia. Academia. https://www.academia.edu/3087073/Is_Tafuri_still_valid_A_contempo rary_reading_of_Architecture_and_Utopia

Ertekin, H. (1981). Mimarlık ve ütopya IV. Mimarlık, 165(3), 11-15.

Gage, M. F. (2016). A Hospice for Parametricism. Architectural Design, 86(2), 128-133.

Geyer, F. (2001). Autopoiesis. ScienceDirect. https://www.sciencedirect.com/topics/social-sciences/autopoiesis

Hardt, M., \& Negri, A. (2000). Empire. President and Fellows of Harvard College.

Jameson, F. (1982). Architecture and the critique of ideology. In K. M. Hays (Ed.), Architecture Theory since 1968 (pp. 440-461). Cambridge, Massachusetts, The MIT Press.

Kamp, I., Veen, S. A. T. V., \& Vink, P. (2015). Comfortable mobile offices: A literature review of the ergonomic aspects of mobile device use in transportation settings. Work, 52(2), 279-287.

Kjerulf, A. (2004). Book Review: The Corrosion of Character. The Chief of Happiness Office Blog. https://positivesharing.com/2004/12/bookreview-the-corrosion-of-character/

Llabres, E., \& Rico, E. (2012). Relational urban models: Parameters, values and tacit forms of algorithms. Architectural Design, 86(2), 84-91.

Magill, F. N. (2005). "The Corrosion of Character" Critical Survey of Contemporary Fiction. Enotes. https://www.enotes.com/topics/corrosion-character

Özmen, Z. (2017). Beyaz yakalı yaşam tarzları: İstanbul ve Ankara örneğinde nitel bir analiz. Phoenix Yayınevi.

Schumacher, P. (2008). Parametricism as Style - Parametricist Manifesto. [Paper presentation]. 11th Architecture Biennale, Dark Side Club, Venice.

Schumacher, P. (2009). A new global style for architecture and urban design. Architectural Design, 79(4), 14-23.

Schumacher, P. (2010a). The parametric city. In Z. Hadid (Ed.), Zaha Hadid: Recent Project. Tokyo, A.D.A Edita.

Schumacher, P. (2010b). Parametricism and the Autopoiesis of Architecture. [Paper presentation]. Lecture by Patrik Schumacher, SCIArc, Los Angeles.

Schumacher, P. (2011). The Autopoiesis of Architecture: A New Framework for Architecture (Vol. 1). John Wiley and Sons.

Schumacher, P. (2012). The Autopoiesis of Architecture: A New Agenda for Architecture (Vol. 2). John Wiley and Sons. 
Schumacher, P. (2013a). Architectural Order via an Agent Based Parametric Semiology. In T. Spyropoulos (Ed.), Adaptive Ecologies Correlated Systems of Living. London: AA Publications.

Schumacher, P. (2013b). Parametric Semiology - The Design of Information Rich Environments. In P. Lorenzo-Eiroa \& A. Sprecher (Eds.), Architecture In Formation - On the Nature of Information in Digital Architecture (pp. 53-59). New York: Routledge.

Schumacher, P. (2014). The Impact of Parametricism on Architecture and Society. In A. Tenorio (Ed.). London.

Schumacher, P. (2015). Parametricism with Social Parameters. In Y. Kahlon (Ed.), The Human Parameter: Parametric Approach in Israeli Architecture. Israel, Paragroup-Israel.

Schumacher, P. (2016a). Advancing social functionality via agent-based parametric semiology. Architectural Design, 86(2), 108-113.

Schumacher, P. (2016b). Design Parameters of Parametric Design. In M. Kanaani \& D. Kopec (Eds.), The Routledge Companion for Architecture Design and Practice (pp. 3-20). New York, Taylor \& Francis.

Schumacher, P. (2016c). Parametricism 2.0: Gearing up to impact the global built environment. Architectural Design, 86(2), 8-17.

Schumacher, P. (2016d). The Concept of Style and Parametricism as Epochal Style. Patrik Schumacher. https://www.patrikschumacher.com/Texts/The\%20Concept $\% 20$ of $\% 2$ 0Style\%20and\%20Parametricism\%20as\%20Epochal\%20Style.html

Schumacher, P. (n.d.-b). On Parametricism (4 ed.): P.A.P.E.R. (Platform for Architectural Projects, Essays \& Research), University of Westminister.

Scolari, M. (1973). The New Architecture and the Avant-Garde. In K. M. Hays (Ed.), Architecture Theory since 1968 (pp. 124-145). Cambridge, Massachusetts, The MIT Press.

Sennett, R. (1998). The Corrosion of Character: The Personal Consequences of Work in the New Capitalism. W. W. Norton \& Company

Sennett, R. (2007). The Culture of the New Capitalism. New Haven: Yale University Press.

Tafuri, M. (1969). Toward a Critique of Architectural Ideology. In K. M. Hays (Ed.), Architecture Theory since 1968 (pp. 2-35). Cambridge, Massachusetts, The MIT Press.

Tafuri, M. (1976). Architecture and Utopia: Design and Capitalist Development (B. L. L. Penta, Trans.). Cambridge, Massachusetts and London, The MIT Press.

\section{Resume}

Nihan Muş Özmen (ITU) is an architect and furniture designer since 2009. In 2017, she worked on the construction site of Erciyes University Congress Centre. In 2017-2019, she worked as a Guest Professor at Erciyes University. In 2019, she completed her master's degree in AGU, Architecture and is currently a Ph.D. student. 
Space Prospect in the Flexible Era of Late Capitalism

Burak Asiliskender (YTU, ITU) is a Professor of architecture at Abdullah Gul University School of Architecture since 2012 and founding chair of the Department of Architecture. He studies, teaches and extensively publishes on architectural history and design approaches of modern movement. He is a member of TICCIH, EAHN, and DOCOMOMO. 